\title{
Cesarean Operative Reports: We Can Do Better!
}

\author{
Sarah E. Goodheart*, Jonathan D. Baum \\ Department of Obstetrics and Gynecology, Jersey Shore University Medical Center, Neptune, USA \\ Email: *Sarah.Goodheart@hmhn.org
}

How to cite this paper: Goodheart, S.E. and Baum, J.D. (2021) Cesarean Operative Reports: We Can Do Better! Open Journal of Obstetrics and Gynecology, 11, 117-124. https://doi.org/10.4236/ojog.2021.112013

Received: January 11, 2021

Accepted: February 22, 2021

Published: February 25, 2021

Copyright $\odot 2021$ by author(s) and Scientific Research Publishing Inc. This work is licensed under the Creative Commons Attribution International License (CC BY 4.0).

http://creativecommons.org/licenses/by/4.0/

\begin{abstract}
Background: The operative report is an essential component of communication, patient care, and safety; it is a JCAHO requirement and legal document. Almost $80 \%$ of residency program directors surveyed agreed on the importance of the operative report, yet less than $20 \%$ of programs provide formal resident training. Documentation has important implications in obstetrics as route and timing of future deliveries are often influenced by operative findings. Purpose: Examine completeness of cesarean operative reports using a validated instrument adapted from general surgery. Assess the impact of an educational resident in-service on the required elements and documentation in resident generated cesarean operative reports. Methods: A quality improvement project identified significant deficiencies in resident generated cesarean operative reports. We conducted a retrospective chart review of cesarean operative reports from November 2019 to May 2020 at Jersey Shore University Medical Center. Our study was conducted in three phases. In phase 1 , a cohort of cesarean operative reports was examined using a structured evaluation tool. In phase 2 , an educational resident in-service on standardization of operative notes was provided. In phase 3, another cohort of cesarean operative reports was examined using the same evaluation tool after the resident in-service. Analysis for improvement was performed. Results: Fifty pre and post-in-service cesarean operative report evaluations were compared $(\mathrm{N}=100)$. Inclusion of date of surgery significantly improved from $78 \%$ to $100 \%$, p-value $<0.001$ and inclusion of history of presents illness (HPI) improved from $34 \%$ to $96 \%$, p-value $<0.001$. Non-significant improvement in presence of a comprehensive description of technique ( $72 \%$ to $86 \%, \mathrm{p}$-value 0.09 ) and findings (94\% to $100 \%$, p-value 0.24$)$ was noted. The remaining elements in the evaluation tool did not have deficiencies before or after the educational resident in-service. Conclusion: Cesarean operative reports can be improved through an educational resident in-service.
\end{abstract}

\section{Keywords}

Cesarean, Documentation, Notes, Operative, Resident 


\section{Introduction}

The operative report is an essential component of communication, patient care, and safety [1]. Elements required by the Joint Commission on the Accreditation of Healthcare Organizations (JCAHO) include history of present illness (HPI), findings, techniques, and operative steps. This documentation has important implications in obstetrics as route and timing of future deliveries are often influenced by operative findings (i.e., adhesions or distorted anatomy), uterine incision type and uterine closure techniques described in a prior cesarean operative report [2].

Almost $80 \%$ of residency program directors surveyed agreed on the importance of the operative report, yet less than $20 \%$ of programs provide formal resident training [3]. Clarke-Pearson outlined the importance of a clear description of anatomic distortion and residual tumor, as this information is essential in the care of gynecologic oncology patients [4]. Since more than one-third of pregnancies are delivered via cesarean, the operative report has become increasingly important in obstetrics as well [3].

A quality improvement assessment at our institution showed $80 \%$ of resident generated cesarean operative reports were missing one or more JCAHO required elements. Our review was based on the standards set by the Canadian Association of General Surgeons and the Structured Assessment Format for Evaluating Operative Reports (SAFE-OR). The goal of this study was to review OBGYN resident generated operative reports for cesarean deliveries to determine adherence to these standards. An educational resident in-service was then conducted with the goal of addressing deficiencies and improving compliance with JCAHO requirements [5].

\section{Materials/Methods}

This retrospective chart review of cesarean operative reports was approved by the Hackensack Meridian Health institutional review board. A quality improvement assessment showed $80 \%$ of resident generated cesarean operative reports were missing one or more JCAHO-required elements. Our primary outcome was to examine deficiencies in resident generated cesarean operative reports. Our secondary outcome was to assess the impact of an educational resident in-service on operative notes. The study was conducted in three phases.

Phase 1: Operative notes were evaluated with a validated tool adapted from general surgery by reading through cesarean operative reports and noting included and omitted required elements from SAFE-OR worksheet. A pre-study evaluation was performed using these guidelines on 50 consecutive resident generated operative reports for cesarean deliveries using the data collection sheet provided by Vergis et al. (see Table 1). Segments were divided into structured elements, HPI, procedure aspects, findings, technique of resection/mobilization, limits of resection, technique of reconstruction, and closure technique. All resident generated cesarean operative notes from November 2019 to January 2020 were collected consecutively to achieve 50 charts. 
Table 1. Structured assessment elements.

Elements Yes
1) Date of surgery
2) Date of dictation
3) Patient identifiers
4) Name of surgeon and assistants
5) Name of anesthetist/anesthesiologist
6) Pre-operative diagnosis
7) Post-operative diagnosis
8) Procedure

9) Brief history of present illness (including relevant investigations)

\begin{tabular}{cccc}
\hline 0 & 1 & 2 & 3 \\
\hline No description & $\begin{array}{c}\text { Preoperative course } \\
\text { and indications } \\
\text { described but some } \\
\text { detail was lacking }\end{array}$ & $\begin{array}{c}\text { Complete } \\
\text { description of } \\
\text { preoperative course } \\
\text { and indications for } \\
\text { procedure }\end{array}$ \\
\hline Procedure & Elements & Yes & No \\
\hline
\end{tabular}

10) Type of anesthesia

11) Skin preparation and draping

12) Patient position

13) Method of abdominal access

14) Findings

\begin{tabular}{|c|c|c|c|c|}
\hline 0 & 1 & 2 & 3 & 4 \\
\hline $\begin{array}{l}\text { No mention of } \\
\text { findings }\end{array}$ & & $\begin{array}{l}\text { Findings stated but } \\
\text { details/explanation } \\
\text { lacking }\end{array}$ & & $\begin{array}{l}\text { Completely } \\
\text { explains findings } \\
\text { and notes } \\
\text { unexpected } \\
\text { findings }\end{array}$ \\
\hline \multicolumn{5}{|c|}{ 15) Technique of resection, including tissue mobilization } \\
\hline 0 & 1 & 2 & 3 & 4 \\
\hline $\begin{array}{l}\text { No description of } \\
\text { mobilization or } \\
\text { resection technique }\end{array}$ & & $\begin{array}{l}\text { Mobilization and } \\
\text { resection techniques } \\
\text { described but } \\
\text { details regarding } \\
\text { operative steps } \\
\text { incomplete }\end{array}$ & & $\begin{array}{l}\text { Complete } \\
\text { description of tissue } \\
\text { mobilization } \\
\text { and method of } \\
\text { resection including } \\
\text { instruments }\end{array}$ \\
\hline
\end{tabular}




\section{Continued}

16) Limits of resection

\begin{tabular}{|c|c|c|c|c|}
\hline 0 & 1 & 2 & 3 & 4 \\
\hline $\begin{array}{l}\text { No anatomical } \\
\text { description of } \\
\text { structures or } \\
\text { mention of } \\
\text { surgical margins }\end{array}$ & & $\begin{array}{l}\text { Resected structures } \\
\text { listed but clear } \\
\text { anatomical } \\
\text { boundaries not } \\
\text { well defined }\end{array}$ & & $\begin{array}{l}\text { Exact anatomical } \\
\text { description } \\
\text { of structures } \\
\text { resected }\end{array}$ \\
\hline \multicolumn{5}{|c|}{ 17) Technique of reconstruction } \\
\hline 0 & 1 & 2 & 3 & 4 \\
\hline $\begin{array}{l}\text { No description } \\
\text { of technique of } \\
\text { reconstruction }\end{array}$ & & $\begin{array}{l}\text { Type of technique } \\
\text { mentioned but } \\
\text { steps and results } \\
\text { of reconstruction } \\
\text { omitted }\end{array}$ & & $\begin{array}{c}\text { Comprehensive } \\
\text { descriptions of } \\
\text { reconstruction } \\
\text { including technique, } \\
\text { equipment used, } \\
\text { and integrity of } \\
\text { repair }\end{array}$ \\
\hline
\end{tabular}

18) Closure technique

\begin{tabular}{|c|c|c|c|c|}
\hline 0 & 1 & 2 & 3 & 4 \\
\hline $\begin{array}{l}\text { No description of } \\
\text { closure method }\end{array}$ & & $\begin{array}{c}\text { Closure described } \\
\text { but specific details } \\
\text { omitted }\end{array}$ & & $\begin{array}{l}\text { Comprehensive } \\
\text { description } \\
\text { including suture } \\
\text { method, size and } \\
\text { type of suture } \\
\text { employed if } \\
\text { applicable }\end{array}$ \\
\hline Elen & & Yes & No & N/A \\
\hline
\end{tabular}

19) Irrigation

20) Drains and location

21) Prosthesis or other items

22) Estimated blood loss (EBL)

23) Dressings applied

24) Sponge and instrument count

25) Specimens sent

Phase 2: Resident in-service educational program on the SAFE-OR standards for operative reports was conducted during resident didactics on $1 / 28 / 2020$. The individual aspects of SAFE-OR were reviewed via printed handouts (see Table 1) for one hour while residents edited their personal operative report templates to include each required element. 
Phase 3: Post-study evaluation on operative note adherence to SAFE-OR guidelines in same manner as phase 1 . All resident generated cesarean operative notes from February 2020 to May 2020 were collected consecutively to achieve 50 charts. The pre and post study results were compared and assessed for improvement.

A sample size of 50 charts $(\mathrm{N}=100)$ before and after the resident in-service was planned assuming an alpha of 0.05 with $80 \%$ to detect a $30 \%$ difference. Pre and post study results were compared using Chi square analysis with $\mathrm{P}$ value < 0.05. We used the Fisher Exact test when expected values were low.

\section{Results}

Pre and post in-service cesarean operative report evaluations were compared. Inclusion of date of surgery significantly improved from $78 \%$ to $100 \%$, p-value < 0.001 , inclusion of irrigation significantly improved from $20 \%$ to $72 \%$, p-value < 0.001 , and inclusion of history of presents illness (HPI) improved from $34 \%$ to $96 \%$, p-value $<0.001$. Non-significant improvement in the inclusion of comprehensive description of technique (72\% to $86 \%$, p-value 0.09$)$ and inclusion of findings ( $94 \%$ to $100 \%$, p-value 0.24 ) was noted.

We found no deficits in the following elements: date of dictation(p-value 1 ), patient identifiers ( $p$-value 1), name of surgeons and assistants ( $\mathrm{p}$-value 1 ), name of anesthesiologist ( $\mathrm{p}$-value 0.49 ), preoperative diagnosis ( $\mathrm{p}$-value 1 ), postoperative diagnosis (p-value 1), procedure (p-value 1$)$, type of anesthesia (p-value 1$)$, skin preparation and draping ( $p$-value 1 ), patient position (p-value 0.204 ), method of abdominal access ( $\mathrm{p}$-value 1), technique of resection ( $\mathrm{p}$-value 1), limits of resection ( $p$-value 0.24 ), closure technique ( $p$-value 1 ), estimated blood loss ( $\mathrm{p}$-value 0.49 ), sponge and instruments counts ( $\mathrm{p}$-value 1), and specimens sent (p-value 1). Elements not relevant to cesarean delivery (i.e. drains, implants, and prosthetics) were omitted from our analysis (Table 2).

\section{Discussion}

The operative report is an essential component of communication, patient care, and safety; it is a JCAHO requirement and legal document. Its purpose is to describe the procedure and operative findings in detail and helpguide physician decision making. JCAHO requires the operative note be completed immediately after the procedure and prior to transferring the patient to the next level of care to avoid omission of important details [6] [7].

Operative reports have become increasingly important in obstetrics. Eicholz et al. (2004) surveyed 270 U.S. Obstetrics and Gynecology residency program directors regarding the importance of operative reports completed by residents. Almost $90 \%$ of those surveyed responded that documenting anoperative report is an important skill to teach, yet only $23 \%$ of programs provide formal training. They also showed that a 30-minute teaching session could objectively improve operative reports [3]. 
Table 2. Impact of Resident in-service on SAFE-OR elements, $\mathrm{n}=100$.

\begin{tabular}{|c|c|c|c|}
\hline Element & Pre & Post & p-value \\
\hline Date of surgery & $78.0 \%(39)$ & $100 \%(50)$ & $<0.001$ \\
\hline Date of dictation & $100 \%(50)$ & $100 \%(50)$ & 1 \\
\hline Patient identifiers & $100 \%(50)$ & $100 \%(50)$ & 1 \\
\hline Name of surgeon and assistants & $98.0 \%(49)$ & $100 \%(50)$ & 1 \\
\hline Name of anesthesiologist & $96.0 \%(48)$ & $100 \%(50)$ & 0.49 \\
\hline Pre-operative diagnosis & $100 \%(50)$ & $100 \%(50)$ & 1 \\
\hline Post-operative diagnosis & $100 \%(50)$ & $100 \%(50)$ & 1 \\
\hline Procedure & $100 \%(50)$ & $100 \%(50)$ & 1 \\
\hline Brief HPI & $34.0 \%(17)$ & $96 \%(48)$ & $<0.001$ \\
\hline Type of anesthesia & $100 \%(50)$ & $100 \%(50)$ & 1 \\
\hline Skin preparation and draping & $100 \%(50)$ & $100 \%(50)$ & 1 \\
\hline Patient position & $90.0 \%(45)$ & $98.0 \%(49)$ & 0.204 \\
\hline Method of abdominal access & $100 \%(50)$ & $100 \%(50)$ & 1 \\
\hline Findings & $94.0 \%(47)$ & $100 \%(50)$ & 0.24 \\
\hline Technique of resection & $100 \%(50)$ & $100 \%(50)$ & 1 \\
\hline Limits of resection & $94.0 \%(47)$ & $100 \%(50)$ & 0.24 \\
\hline $\begin{array}{l}\text { Technique of reconstruction } \\
\text { (i.e. uterine incision and/or closure) }\end{array}$ & $72.0 \%(36)$ & $86.0 \%(43)$ & 0.09 \\
\hline Closure technique & $100 \%(50)$ & $100 \%(50)$ & 1 \\
\hline Irrigation & $20.0 \%(10)$ & $72.0 \%(36)$ & $<0.001$ \\
\hline Estimated blood loss & $96.0 \%(48)$ & $100 \%(50)$ & 0.49 \\
\hline Dressings applied & $94.0 \%(47)$ & $100 \%(50)$ & 0.24 \\
\hline Sponge and instrument count & $100 \%(50)$ & $100 \%(50)$ & 1 \\
\hline Specimens sent & $100 \%(50)$ & $100 \%(50)$ & 1 \\
\hline
\end{tabular}

Moore (2000) surveyed 52 general surgery residency program directors about their operative report curriculum. Only $31 \%$ reported formal instruction during their own training [8]. Goodman (1983) commented that "even standard textbooks give little or no information to the young surgeon on the how, why and what is to be included in an operative report [7]." Those who had no formal instruction said they learned from reading notes of senior residents and attending physicians.

Given the overall importance of operative reports, an operative report curriculum should be part of formal resident training. Particular attention should be 
focused on inclusion of the HPI, operative technique (i.e. uterine incision type and closure) and anatomical findings. In addition, missing information in an operative report can negatively impact patient care. A report that lacks a description of uterine closure technique may dissuade a trial of labor after cesarean (TOLAC). The impact of operative reports on willingness to pursue or allow TOLAC requires further study. The importance of an operative report in reviews of care and in the defense of lawsuits cannot be overlooked.

Strengths of this study include the use of validated measures to quantify deficiencies and improvement, analysis powered to detect a 30\% difference between pre and post resident in-service, and generalizability to other surgical specialties. A weakness of this study is that it was not powered to detect a significant difference in every aspect of the SAFE-OR assessment. Pre in-service deficiencies in some aspects were not as profound and therefore did not reach statistical significance. The $6.4 \%$ increase in documentation of operative findings and $19.4 \%$ improvement in documentation of technique, if confirmed in a larger sample, are clinically relevant improvements.

\section{Conclusion}

Our analysis shows that resident generated cesarean operative reports can be improved through an educational resident in-service. We believe that this essential documentation skill should be part of the curriculum in all OBGYN residencies with the goal of improving communication, patient care, and safety. We can do better!

\section{Disclosures}

The authors have nothing to disclose.

\section{Conflicts of Interest}

The authors declare no conflicts of interest regarding the publication of this paper.

\section{References}

[1] American College of Obstetricians (2007) ACOG Committee Opinion No.367.: Communication Strategies for Patient Handoffs. Obstetrics and Gynecology, 109, 1503-1505. https://doi.org/10.1097/01.AOG.0000263904.16706.41

[2] American College of Obstetricians (2010) ACOG Practice Bulletin No. 115: Vaginal Birth after Previous Cesarean Delivery. Obstetrics and Gynecology, 116, 450-463. https://doi.org/10.1097/AOG.0b013e3181eeb251

[3] Eichholz, A.C., et al. (2004) Operative Note Dictation: Should It Be Taught Routinely in Residency Programs? Obstetrics and Gynecology, 103, 342-346. https://doi.org/10.1097/01.AOG.0000109521.44989.53

[4] Clarke-Pearson, D.L. (2003) Your Operative Note: Friend or Foe? Audio-Digest Obstetrics/ Gynecology, 50.

[5] James, P.B. (2013) Preventing the First Cesarean Delivery. Obstetrics \& Gynecology, 
121, 878-879. https://doi.org/10.1097/AOG.0b013e31828a82b5

[6] Joint Commission on Accreditation of Healthcare Organizations (2020) Record of Care and Treatment Services. Joint Commission Journal on Quality and Patient Safety.

[7] Goodman, R. (1983) The Operative Report: A Medical Record or a Legal Document. Orthopedics, 6, 941-945.

[8] Moore, R.A. (2000) The Dictated Operative Note: Important but Is It Being Taught? Journal of the American College of Surgeons, 190, 639-640.

https://doi.org/10.1016/S1072-7515(00)00247-7 